\title{
Historical and Future Extreme Temperature Indices of Greater Cairo Region, Egypt
}

Gamil Gamal $^{1}$

\begin{abstract}
The main objective of this work to analyze the historical trend of the temperature extreme indices for Greater Cairo Region from 1948 until 2015, by using NCEP reanalysis daily data for minimum and maximum temperatures. Ten extreme temperature indices such as summer days, tropical nights, warm and cold days, warm and cold nights, were calculated for four stations located inside the domain of The Greater Cairo Region such as Cairo, Bahtim, Giza and Helwan. This historical period divided into two short periods, the first from 1948 until 1978 and the second from 1979 until 2015. The results show that there is a significant difference between the two periods. The trend of tropical nights for Cairo station (1948-1978) was negative while the trend for the same station was significantly positive during (1979-2015), also Giza station has the same result for tropical night. Future assessment of extreme temperature indices (2020-2100) was done by using three CMIP5 global climate model with two representative concentration pathway scenarios RCP4.5 and RCP8.5. From future probability distribution function of temperature extremes over Cairo station, a strong shift in mean for summer days at RCP8.5 more than RCP4.5 which will lead to more hot weather and less cold weather. Future projection of climate extremes can help in management and adaptation strategies. [Bul. Soc. Géog. d'Égypte, 2019, 92: 40-52]
\end{abstract}

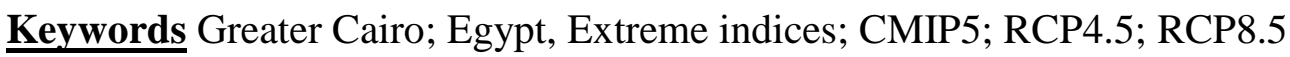

\section{Introduction}

The mean temperatures of the global increase since the mid-twentieth century due to the observed increase in the greenhouse gases concentrations (IPCC, 2007). In addition, the extremes themselves might change so as to bring about changes that are bigger than would basically come about because of the movement of variability to a higher level (Hegerl and others, 2004; IPCC, 2007). Variability of the extreme weather events has critical impacts and embarrass remarkable challenges to society (CCSP, 2008). Extreme climate indices come in the tails of a probability distribution of climate variables, such as rainfall and temperature.

Conception the mechanisms related with extreme indices at the local scale could supply helpful insights for stakeholders, system administrators, and policy makers to mitigate economic losses. Therefore, worldwide research work is decisive to assess the mechanization and effects of extreme events in a global context. Previously researchers have shown that changes in the frequency and intensity of climate extremes such as (Frei and Schär 2001; Frich et al. 2002; Kiktev et al. 2003; Sen Roy and Balling 2004; Vincent et al. 2005; Aguilar et al. 2005; Moberg and Jones 2005; Alexander et al. 2006; New et al. 2006; Dos Santos et al. 2010; Wong et al. 2010; Hirschi et al. 2011; Gamal 2017).

Soltani et al (2015), studied the changes in spatiotemporal patterns of climate extremes indices over Iran for the period (1975-2010). Temperature extremes show a significant positive trend for all indices over sub-period (1995-2010). The number of clod days and nights decreased by 4 and 3 days/decade and the warm days and nights number also increased by 13 days/decade. By using RClimDex package based on R, Almazroui et al (2014), analysed extreme temperature indices for Saudi Arabia for the period 1981-2010. Results indicated that about $93 \%$ from 27 stations used in their work has significant increase in warm temperature indices and significant decreased for cold extremes.

\footnotetext{
${ }^{1}$ Department of Natural Resources, Faculty of African Postgraduate Studies,Cairo University, Egypt E-mail: gamil.gamal@cu.edu.eg
} 
The daily trend of extreme temperature over three different eco-environments in Ethiopia (1967-2008) were investigated by Mekasha et al (2014). Their results indicated positive trends for maximum value of the maximum temperature (TXx), warm days (TX90p), warm nights (TN90p) and warm spell duration indicators (WSDI) and negative trends for cool days (TX10p), cool nights (TN10p) and cold spell duration indicators (CSDI) in more than 8 of the 11 stations studied. Panda et al (2014), studied the spatial and temporal patterns of extreme temperature in India from 1971 to 2005. They found that the daily minimum temperature, has increased which followed by a decreases in cold extremes in large parts of the country. Also warming temperature indices tend to increase in the year following the El Niño events. In Portugal, Santo et al (2014), indicated the seasonal trend of temperature for the period 1941 until 2006. They found that hot extreme temperature such as hot days and tropical night increased and associated with significant increase in the duration and frequency of heat waves in spring and summer, a significant decrease of clod extreme also detected.

Nandintsetseg et al (2007), investigated the temperature extremes near Lake Hövsgöl, Mongolia (1963-2002). Their results show a significant increase in the hot extreme temperature indices such summer days and tropical nights and decrease in the cold extremes such as cold days and cold nights numbers. While Manton et al (2010), studied the daily temperature extremes from 1961 to 1998 for Southeast Asia and the South Pacific. Significant increases were detected in the annual number of hot days and warm nights, with significant decreases in the annual number of cool days and cold nights. Also Salinger and Griffiths (2001), investigated the daily trend for both temperature and rainfall over New Zealand for the period (1951-1998). The paper results show that there was no significant increase in hot days number but a significant increase in minimum temperature associated with decrease in cold days number. Frost days frequency decreased and days with $25{ }^{\circ} \mathrm{C}$ increased at the north eastern part only [Bul. Soc. Géog. d'Égypte, 2019, 92: 40-52].

\section{Methodology}

\section{$\underline{2.1 \text { Target area }}$}

Greater Cairo Region (GCR), located south of Nile Delta. It is classified as the largest urban area in Africa and one of the world's 15 largest cities in urban and population growth. Population in GCR exceeds 15 million concentrated over an area of about $214,000 \mathrm{~km}^{2}$. The urbanization and industrialization have increased very rapidly in GCR, especially in the second half of the last century (Robaa, 2003). Greater Cairo and the surrounding area belongs to a hot desert climate (BWh) in Köppen classification, as all of Egypt. 


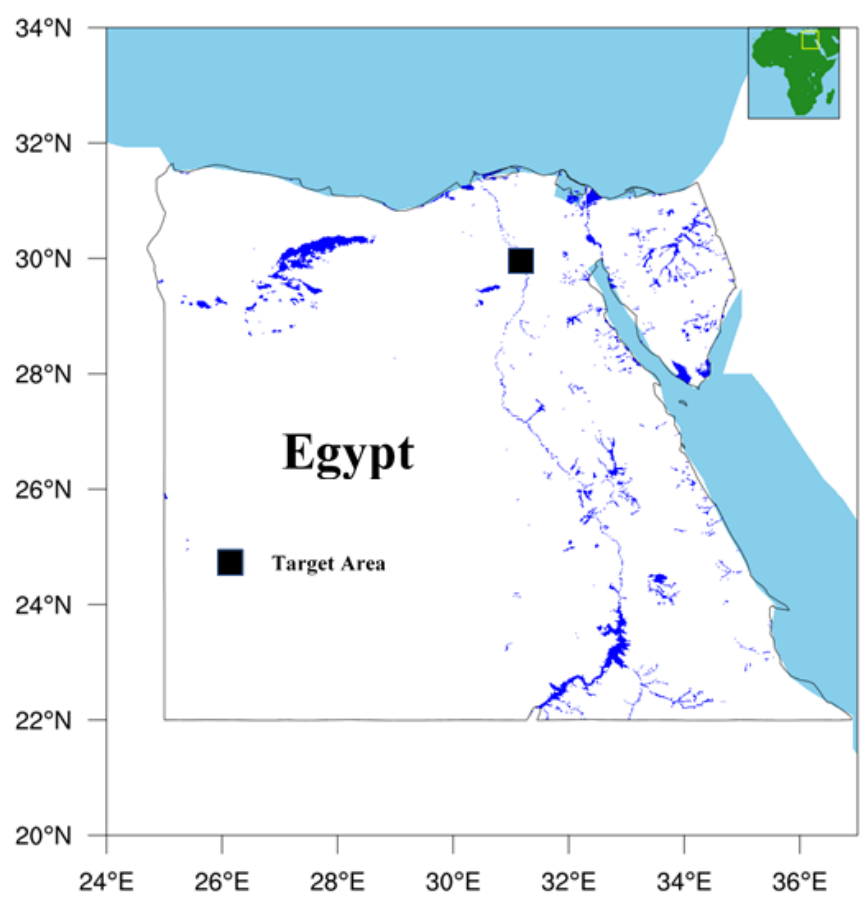

Fig 1. Egypt map which the black box is the target area

The target area has been presented by four selected meteorological stations situated inside GCR and represent different degrees of urbanization as shown in table 1.

Table (1), GCR region ground stations

\begin{tabular}{|l|c|c|c|}
\hline \multicolumn{1}{|c|}{ Station name } & Station WMO no. & Latitude & Longitude \\
\hline Bahtim Agrimet. & 62369 & 30.14 & 31.26 \\
\hline Cairo & 62366 & 30.11 & 31.41 \\
\hline Giza - Agrimet. & 62375 & 30.05 & 31.22 \\
\hline Helwan & 62378 & 29.86 & 31.35 \\
\hline
\end{tabular}

\subsection{Data and Methods}

Daily minimum and maximum temperatures of the NCEP/NCAR Reanalysis 1 project (Kalnay et al, 1996) was used for four stations located in the greater Cairo region from 1948 until 2015. The calculation of the extreme temperature indices has performed by ClimPACT2 (Alexander and Herold, 2016). The plurality of extreme indices in ClimPACT2 determined using code from the climdex. pcic R package which was developed by the Pacific Climate Impacts Consortium (PCIC). The ClimPACT2 is the updates of ClimPACT software which was based on the RClimDEX software developed by the WMO CCl/WCRP/JCOMM Expert Team on Climate Change Detection and Indices (ETCCDI). ClimPACT2 is an R software package for calculating the 34 core indices. It has two methods for calculating these indices, through a Graphical User Interface and through the climpact.loader for those is meant for users experienced with the $\mathrm{R}$ programming language. The only requirement to run the ClimPACT2 GUI is that the R software package is installed, then download ClimPACT2 from github, (https://github.com/ARCCSS-extremes/climpact2/archive/master.zip). Table (2) describes only the extreme climate indices calculated over Greater Cairo stations. 
Table (2), extreme climate indices calculated by ClimPACT2

\begin{tabular}{|c|c|c|c|}
\hline $\begin{array}{l}\text { short } \\
\text { name }\end{array}$ & Long name & Definition & Uni \\
\hline CSDI & $\begin{array}{l}\text { Cold spell duration } \\
\text { indicator }\end{array}$ & $\begin{array}{l}\text { Annual number of days with at least } 6 \text { consecutive } \\
\text { days when } \mathrm{TN}<10 \text { th percentile }\end{array}$ & days \\
\hline WSDI & $\begin{array}{l}\text { Warm spell duration } \\
\text { indicator }\end{array}$ & $\begin{array}{l}\text { Annual number of days with at least } 6 \text { consecutive } \\
\text { days when TX }>90 \text { th percentile }\end{array}$ & days \\
\hline SU30 & hot days & Annual number of days when $\mathrm{TX}>=30^{\circ} \mathrm{C}$ & days \\
\hline $\mathrm{TR}$ & Tropical nights & Annual number of days when $\mathrm{TN}>20^{\circ} \mathrm{C}$ & days \\
\hline TN10p & Amount of cold nights & Percentage of days when $\mathrm{TN}<10$ th percentile & $\%$ \\
\hline TN90p & Amount of hot nights & Percentage of days when TN > 90th percentile & $\%$ \\
\hline TX10p & Amount of cool days & Percentage of days when $\mathrm{TX}<10$ th percentile & $\%$ \\
\hline TX90p & Amount of hot days & Percentage of days when TX > 90th percentile & $\%$ \\
\hline TMm & Mean TM & Mean daily mean temperature & ${ }^{\circ} \mathrm{C}$ \\
\hline $\mathrm{TNm}$ & Mean TN & Mean daily minimum temperature & ${ }^{\circ} \mathrm{C}$ \\
\hline $\mathrm{TNn}$ & Min TN & Coldest daily $\mathrm{TN}$ & ${ }^{\circ} \mathrm{C}$ \\
\hline TNx & Max TN & Warmest daily TN & ${ }^{\circ} \mathrm{C}$ \\
\hline TXm & Mean TX & Mean daily maximum temperature & ${ }^{\circ} \mathrm{C}$ \\
\hline TXn & Min TX & Coldest daily TX & ${ }^{\circ} \mathrm{C}$ \\
\hline TXx & Max TX & Warmest daily TX & ${ }^{\circ} \mathrm{C}$ \\
\hline
\end{tabular}

\section{$\underline{3 \text { Results and Discussion }}$}

As shown in table 3, which explains the trend of different extreme climate indicators for each station and for two periods, the first is (1948-1978) and the second period is (19792015). The index of monthly maximum value for daily maximum temperature (TXX) shows an increasing insignificant trend at almost of the stations, while the monthly maximum value for daily minimum temperature (TNx) shows an increasing significant trend for the four stations. From Table 3 it is clear that all stations show positive trends for these two indices. The monthly minimum values of daily maximum temperature (TXn) have increased at all stations insignificantly. The monthly minimum values of daily minimum temperature (TNn) have insignificantly increase at four stations. The annual occurrence of cool days (TX10p) at Fig.2-A shown a significant decreasing trend at the four stations. In a similar pattern, cool nights (TN10p) have significantly decreased at all stations. The extreme index of warm days (TX90p), at Fig.3-A shown insignificantly increasing trend at the selected stations, except for one station (Giza) located in the southwestern part of the GCR, which shown a significant increasing trend. Warm nights (TN90p) also have significantly increased at all stations.

The Cold Spell Duration Indicator (CSDI), at Fig.3-B has decreased at all stations with significant trends. While the Warm Spell Duration Indicator (WSDI) at Fig.3-C has increased for all stations with insignificant trends. The decrease of CSDI and increase of 
WSDI is in agreement with the decrease of TN10p and increase of TX90p, which are directly related to the warming of air temperatures. Of all the observed trends in the selected extreme indices, the remarkably increase of WSDI in 2010 is very alarming and should become a great concern for relevant stakeholders such as government planners, community, and industrialists in terms of dealing with global warming and climate change-related issues. The Tropical Nights where the minimum temperature higher than $20{ }^{\circ} \mathrm{C}$ (TR20), have also shown significantly increasing trends for all stations, which significantly increasing at $95 \%$ level, this finding clearly indicates that the warming is evident; and it could also be taken as a signal of climate change at the local level.

Table (3), trend values for extreme temperature indices over GCR

\begin{tabular}{|c|c|c|c|c|c|c|c|c|}
\hline Station & \multicolumn{2}{|c|}{ Cairo } & \multicolumn{2}{|c|}{ Giza } & \multicolumn{2}{|c|}{ Helwan } & \multicolumn{2}{|c|}{ Bahtim } \\
\hline & $1^{\text {st }}$ & $2^{\text {nd }}$ & $1^{\mathrm{st}}$ & $2^{\text {nd }}$ & $1^{\mathrm{st}}$ & $2^{\text {nd }}$ & $1^{\mathrm{st}}$ & $2^{\text {nd }}$ \\
\hline CSDI & 0.03 & -0.1 & 0.04 & -0.1 & 0.01 & -0.1 & 0.1 & -0.1 \\
\hline WSDI & $-0.5^{*}$ & $0.44 *$ & $-0.5 *$ & $0.4^{*}$ & $-0.5^{*}$ & $0.4^{*}$ & $-0.55^{*}$ & 0.43* \\
\hline SU30 & -0.2 & 0.2 & -0.33 & 0.3 & -0.5 & 0.3 & -0.2 & 0.2 \\
\hline SU35 & 0.03 & 0.02 & 0.03 & 0.01 & 0.03 & 0.02 & 0.02 & 0.02 \\
\hline TR & -0.4 & $0.6^{*}$ & -0.4 & 0.6* & -0.4 & $0.5^{*}$ & -0.4 & 0.6 \\
\hline TN10p & 0.2 & $-0.3^{*}$ & 0.2 & $-0.25 *$ & $0.21 *$ & $-0.24 *$ & 0.2 & $-0.3^{*}$ \\
\hline TN90p & $-0.3^{*}$ & $0.3^{*}$ & $-0.3^{*}$ & $0.3^{*}$ & $-0.3^{*}$ & $0.3^{*}$ & $-0.3^{*}$ & $0.3^{*}$ \\
\hline TX10p & 0.05 & -0.1 & 0.05 & -0.1 & 0.1 & -0.1 & 0.04 & -0.1 \\
\hline TX90p & -0.2 & 0.1 & -0.2 & 0.1 & -0.2 & 0.1 & -0.15 & 0.1 \\
\hline $\mathrm{TNn}$ & -0.1 & -0.01 & -0.05 & -0.01 & -0.05 & -0.01 & -0.05 & -0.01 \\
\hline TNx & -0.02 & $0.04 *$ & -0.02 & 0.041* & -0.02 & 0.04* & -0.02 & 0.04* \\
\hline TXn & -0.01 & -0.01 & -0.01 & -0.02 & -0.01 & -0.01 & -0.01 & -0.01 \\
\hline TXx & -0.002 & 0.02 & 0.001 & 0.02 & 0.002 & 0.02 & -0.002 & 0.02 \\
\hline
\end{tabular}

The bold value with $*$ is statistically significant at 0.05 level

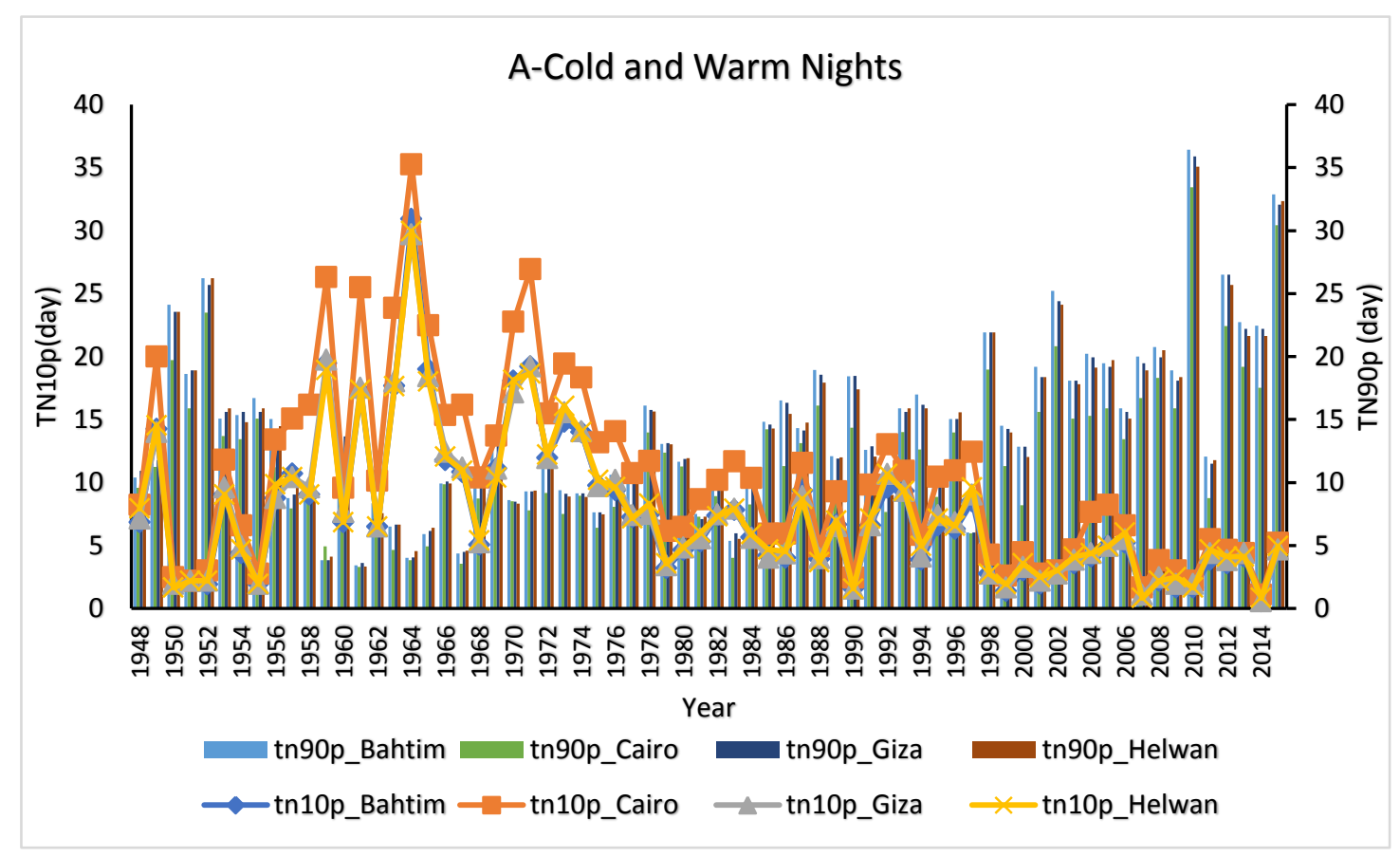

Fig (2), annual variations of, (A) cold and warm nights indices for Bahtim, Cairo, Giza and Helwan 

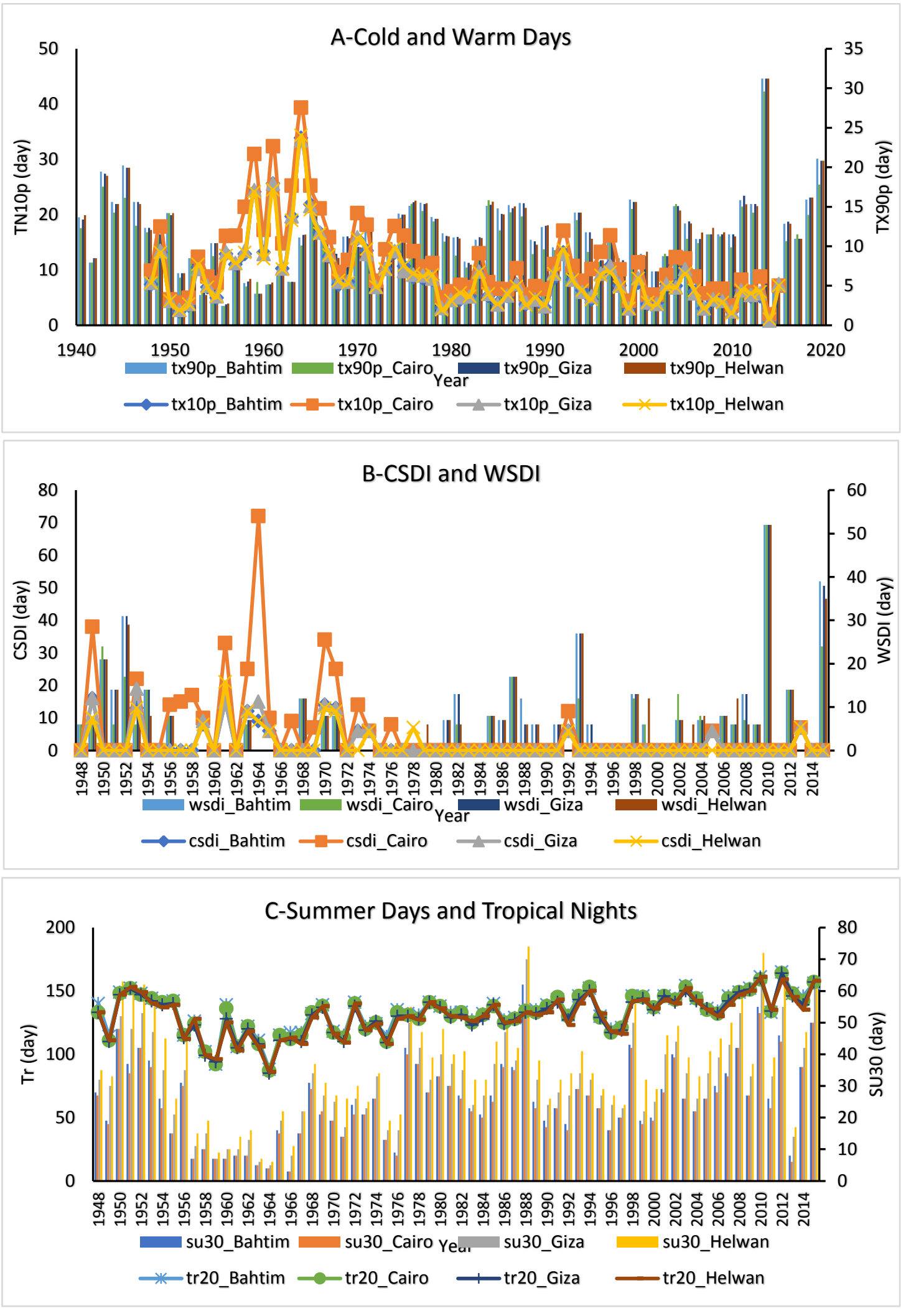

Fig (3), annual variations of, (B) cold and warm days, (C) summer days and tropical nights, and (D) CSDI and WSDI for Bahtim, Cairo, Giza and Helwan 


\section{Assessment of future variability for the extreme indices over Cairo:}

The frequency, duration, spatial, adversity and timing of both weather and climate extreme events would effected by any perturbations in climate, which can lead to surpassing climate events and weather extremes. Future changes in exposure, sensitivity, and climate extremes resulting from natural climate variability, anthropogenic climate change, and socioeconomic growth can modify the impacts of climate extremes on natural and human systems and the possibility for scourges. Variability in extremes can be related to changes in the average, variance, or probability distributions shape, or all of these as shown in (Figure 3 ). The assessment and forecast of regarding climate change extremes and weather events is one of the utmost affronts of the scientific groups as they have a main action in natural and socioeconomic sections (Kostopoulou and Jones, 2005) such as water resources, ecosystems, agriculture, and health (Parry, 2000). Excessive temperature climatic statues are linked with increased energy consuming, devolution of human relief and tourism (Henderson and Muller, 1997; Subak et al., 2000).

The indices of the climate extremes which defined by the Expert Team on Climate Change Detection and Indices (ETCCDI) are computed for a number of global climate models participating in the Coupled Model Intercomparison Project Phase 3 (CMIP3) and Phase 5 (CMIP5), and reanalyses, presented in Sillmann et al. (2013a, b). At this part, six extreme climate indices which are summer days (SU), tropical nights (Tr), warm and cold nights (TN10p, TX10p), also warm and cold days (TN90p, TX90p), downloaded for three different global models (GFDL-ESM2M), (HadGEM2-ES) and (MPI-ESM-MR) under two different representative concentration pathway scenarios RCP4.5 and RCP8.5. The ensemble mean calculated for each indices and compared with the probability distribution of the historical record (1948/2015).

As shown in Fig (4), which describe the probability distribution for each climate index over Cairo during the period (2020/2100). Summer days and tropical nights calculated as days, while warm and cold indices calculated as percentage, so it has been converted into days for easier conception.

The results of future assessment of the extreme climate indices can be summarized as follow:

1- For summer days (SU), (Fig 4A), there is a strong shift in mean for both RCP4.5 and RCP8.5 compared to observational probability distribution, but the variability also increased for SU at RCP8.5 than RCP4.5 which will lead to more hot weather and less cold weather.

2- For tropical nights (Tr), (Fig 4B), a shift in mean with less variability for RCP4.5 distribution, while RCP8.5 has increasing variability with mean shifting.

3- For cold nights, TN10p, (Fig. 4C) and cold days, TX10p, (Fig. 4D), the frequencies of the cool days and cool nights have decreased, whereas the frequencies of annual occurrence of warm days and warm nights have increased over Cairo, as shown in (Fig. 4E) for TN90p and (Fig. 4F) for TX90p.

\section{Conclusion}

Investigation of the temperature extremes indices are very substantial for feasible socio-economic objectives. For example, such awareness would assist Egyptian-related stakeholders and authorities to achieve power supplies agriculture, tourism and water resources, which are immediately impacted by the temperature fluctuation in the country. It is clear that summer days and tropical nights have a significant increasing as seen in Figure 3 by 
shifting mean and variability which lead to more hot weather and less cold weather record. The cold extreme indices, cold days and nights have significant decrease and this trend will continue in the future under different scenarios, while hot extreme indices, warm days and nights have significant increase trend.

In general, the extent of extremes associated with global warming has been increasing at the target area. It is subsequently concluded that the climate of Greater Cairo Region has sophisticated a warming trend associated with the increase of temperature extremes. This indicates that heat waves are increasing greatly in this region. Besides large-scale global warming and atmospheric circulation, the driving force behind this changing climate could be the changes in cloud cover (Duan and $\mathrm{Wu}, 2006$ ). Other non-climatic contributing factors also could be attributed the possible influence of aerosols in industrial regions, as noted by some researchers (e.g. Stone and Weaver, 2003; Trenberth et al., 2007; Zhou et al., 2009). 

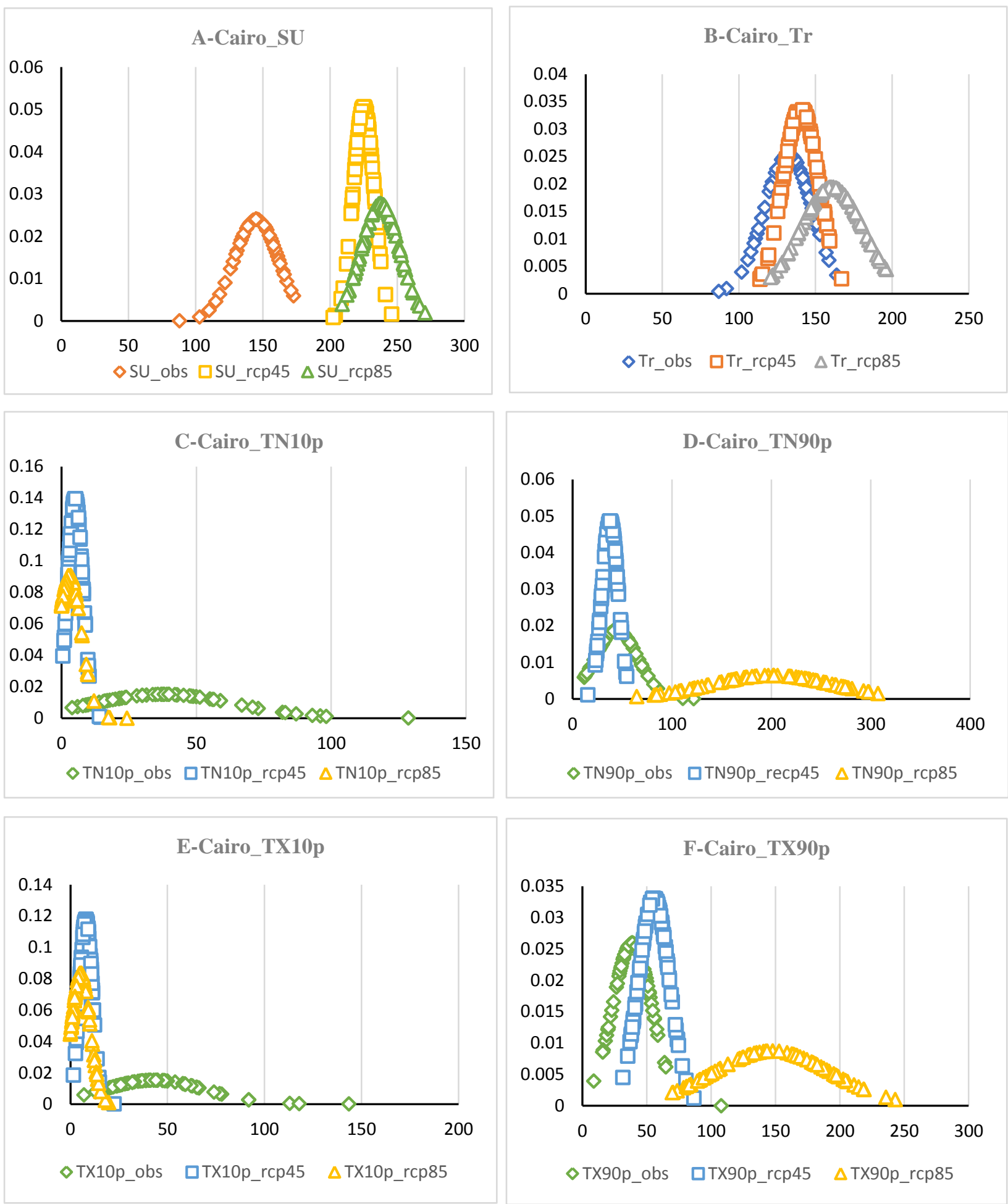

Fig (4), probability of distribution for, (A) summer days, (B) tropical nights, (C) cold nights, (D) cold days, (E) warm nights, and (F) warm days for Cairo (2020/2100). 


\section{References}

Aguilar E, Peterson TC, Obando PR, Frutos R, Retana JA, Solera M, Soley J, Gonzalez Garcia I, Araujo RM, Rosa Santos A, Valle VE, Brunet M, Auilar L, Alvarez L, Bautista M, Castaiion C, Herrera L, Ruano E, Sinay JJ, Sanchez E, Hernadez Oviedo GI, Obed F, Salgado JE, Vazquez JL, Baca M, Gutierrez M, Centella C, Espinosa J, Martinez D, Olmedo B, Ojeda Espinoza CE, Nunez R, Haylock M, Benavides H, Mayorga R (2005) Changes in precipitation and temperature extremes in Central America and northern South America, 1961-2003. J Geophys Res. doi: 10.1029/ 2005JD006119. Available at http://onlinelibrary.wiley.com/doi/10.1029/2005JD006119/full. Accessed 10 July 2016

Alexander LV, Zhang X, Peterson TC, Caesar J, Gleason B, Tank A, Haylock M, Collins D, Trewin B, Rahimzadeh F, Tagipour A, Kumar KR, Revadekar J, Griffiths G, Vincent L, Stephenson DB, Burn J, Aguilar E, Brunet M, Taylor M, New M, Zhai P, Rusticucci M, Vazquez-Aguirre JL. (2006) Global observed changes in daily climate extremes of temperature and precipitation. J Geophys Res-Atmos 111(D5). doi:10.1029/2005jd006290. Available at http://onlinelibrary.wiley.com/doi/10.1029/2005JD006290/full. Accessed 15 July 2016

Almazroui M. Islam M. N. Dambul R. Jones P. D., (2014), Trends of temperature extremes in Saudi Arabia, Int. J. Climatol. 34:808-826, DOI:10.1002/joc.3722. Available at http://onlinelibrary.wiley.com/doi/10.1002/joc.3722/full. Accessed 15 July 2016

CCSP (2008) Weather and climate extremes in a changing climate. Regions of focus: North America, Hawaii, Caribbean, and U.S. Pacific Islands. A report by the U.S. climate change science program and the subcommittee on global change research. [Thomas R. Karl, Gerald A. Meehl, Christopher D. Miller, Susan J. Hassol, Anne M. Waple and William L. Murray (eds.)]. Department of Commerce, NOAA's National Climatic Data Center, Washington, D.C., USA, 164 pp. Available at https://digital.library.unt.edu/ark:/67531/metadc12026/m2/1/high_res_d/sap3-3final-all.pdf. Accessed 16 July 2016

Dos Santos CAC, Neale CMU, Rao TVR, Da Silva BB (2010) Trends in indices for extremes in daily temperature and precipitation over Utah USA. Int J Climatol. doi:10.1002/joc. 2205. Available at http://onlinelibrary.wiley.com/doi/10.1002/joc.2205/full. Accessed 1 August 2016

Frei C, Schär C (2001) Detection probability of trends in rare events: theory and application to heavy precipitation in the Alpine Region. J Climate 14:1568-1584. Available at $\quad$ http://journals.ametsoc.org/doi/pdf/10.1175/15200442\%282001\%29014\%3C1568\%3ADPOTIR\%3E2.0.CO\%3B2. Accessed 1 August 2016 
Frich P, Alexander LV, Della-Marta P, Gleason B,HaylockM, Klein Tank AMG, Peterson T (2002) Observed coherent changes in climatic extremes during the second half of the twentieth century. Clim Res 19:193-212. Available at http://www.int-res.com/articles/cr2002/19/c019p193.pdf. Accessed 2 August 2016

Gamal, G. 2017. Future Analysis of Extreme Temperature Indices for Sinai PeninsulaEgypt. Imperial Journal of Interdisciplinary Research (IJIR) . 3:1960-1966

Hirschi M, Seneviratne SI, Alexandrov V, Boberg F, Boroneant C, Christensen OB, Formayer H, Orlowsky B, Stepanek P (2011) Observational evidence for soilmoisture impact on hot extremes in southeastern Europe. Nat Geosci. doi:10.1038/NGEO1032 Available http://www.nature.com/ngeo/journal/v4/n1/full/ngeo1032.html. Accessed 3 August 2016

IPCC, 2007, Summary for policymakers (Contribution of Working Group 1 to the Fourth Assessment Report of the Intergovernmental Panel on Climate Change), Climate Change, 2007: the physical science basis, Cambridge Univ. Press, New York, USA. Available at https://www.ipcc.ch/pdf/assessment-report/ar4/wg1/ar4-wg1spm.pdf. Accessed 5 August 2016

Kalnay et al.,The NCEP/NCAR 40-year reanalysis project, Bull. Amer. Meteor. Soc., 77, 437-470, 1996.

Kiktev D et al. (2003) Comparison of modeled and observed trends in indices of daily climate extremes. J Clim 16:3560-3571. Available at http://journals.ametsoc.org/doi/full/10.1175/1520-

0442\%282003\%29016\%3C3560\%3ACOMAOT\%3E2.0.CO\%3B2. Accessed 6 August 2016

Manton MJ (2010), Trends in climate extremes affecting human settlements, Curr. Opin. Environ. Sustain. 2(3):151-155. Doi: 10.1016/j.cosusts.2010.05.001. Available at http://www.sciencedirect.com/science/article/pii/S1877343510000229. Accessed 31 August 2016

Mekasha A, Tesfaye K, Duncan AJ (2013) Trends in daily observed temperature and precipitation extremes over three Ethiopian eco-environments. Int. J. Climatol. 34: 1990-1999. DOI: 10.1002/joc.3816. Available at http://onlinelibrary.wiley.com/doi/10.1002/joc.3816/full. Accessed 31 August 2016

Moberg A, Jones PD (2005) Trends in indices for extremes in daily temperature and precipitation in central and Western Europe, 1901-1999. Int J Climatol 25:11491171. Available at http://onlinelibrary.wiley.com/doi/10.1002/joc.1163/pdf. Accessed 31 August 2016

Nandintsetseg B, Greene JS, Goulden CE (2007) Trends in extreme daily precipitation and temperature near Lake Hövsgöl, Mongolia. Int. J. Climatol. 27: 341-347. DOI:

$10.1002 /$ joc. 1404 . Available

at http://onlinelibrary.wiley.com/doi/10.1002/joc.1404/epdf. Accessed 31 August 2016 
New M, Hewitson B, Stephenson DB et al. (2006) Evidence of trends in daily climate extremes over southern and west Africa. J Geophys Res Atmos 111:D14102. doi:10.1029/2005JD006289. Available at http://onlinelibrary.wiley.com/doi/10.1029/2005JD006289/full. Accessed 31 August 2016

Panda DK, Mishra A, Kumar A, Mandal KG, Thakur AK, Srivastava RC (2014) Spatiotemporal patterns in the mean and extreme temperature indices of India, 1971-2005. Int. J. Climatol. 34: 3585-3603. DOI: 10.1002/joc.3931. Available at https://wle.cgiar.org/cgspace/resource/10568-58382. Accessed 31 August 2016

Salinger MJ, Griffiths GM (2001) Trends in New Zealand daily temperature and rainfall extremes. Int. J. Climatol. 21: 1437-1452. DOI: 10.1002/joc.694. Available at http://onlinelibrary.wiley.com/doi/10.1002/joc.694/full. Accessed 31 August 2016

Santo F, De Lima M, Ramos A, Trigo R (2014) Trends in seasonal surface air temperature in mainland Portugal, since 1941. Int. J. Climatol. 34: 1814-1837. DOI: $\quad$ 10.1002/joc.3803.Available at: http://onlinelibrary.wiley.com/doi/10.1002/joc.3803/full. Accessed 31 August 2016

Sen Roy S, Balling RC (2004) Trends in extreme daily precipitation indices in India. Int J Climatol 24:457-466. Available at http://onlinelibrary.wiley.com/doi/10.1002/joc.995/pdf. Accessed 31 August 2016

Sillmann, J., V. V. Kharin, F. W. Zwiers, X. Zhang, and D. Bronaugh, 2013a: Climate extremes indices in the CMIP5 multi-model ensemble. Part 1: Model evaluation in the present climate.J. Geophys. Res., doi:10.1002/jgrd.50203. Available at http://onlinelibrary.wiley.com/doi/10.1002/jgrd.50203/full. Accessed 15 August 2016

Sillmann, J., V. V. Kharin, F. W. Zwiers, X. Zhang, and D. Bronaugh, 2013b: Climate extremes indices in the CMIP5 multi-model ensemble. Part 2: Future projections. J. Geophys. Res., doi:10.1002/jgrd.50188. Available at http://onlinelibrary.wiley.com/doi/10.1002/jgrd.50188/full. Accessed 15 August 2016

Soltani M., Laux P., Kunstmann H., Sohrabi M., Molanejad M., Sabziparvar A., Abadi A., Ranjbar F., Rousta I., Zawar-Reza P., Khoshakhlagh F., Soltanzadeh I., Babu C., Azizi G., 2015, Assessment of climate variations in temperature and precipitation extreme events over Iran, 2015, Theor. Appl. Climatol, Doi: 10.1007/s00704-015-1609-5. Available at http://link.springer.com/content/pdf/10.1007\%2Fs00704-015-1609-5.pdf. Accessed 31 August 2016

Vincent LA et al. (2005) Observed trends in indices of daily temperature extremes in South America 1960-2000. J Clim 18(23):5011-5023. Available at 
http://journals.ametsoc.org/doi/full/10.1175/JCLI3589.1. Accessed 31 August 2016

Wong MC, Mok HY, Lee TC (2010) Observed changes in extreme weather indices in Hong Kong. Int J Climatol. doi:10.1002/joc.2238. Available at http://onlinelibrary.wiley.com/doi/10.1002/joc.2238/full. Accessed 31 August 2016

الهذف الرئيسي من هذا البحث هو تحليل الاتجاه العام لمؤشرات درجة الحرارة القصوى لمنطقة القاهرة الكبرى من عام

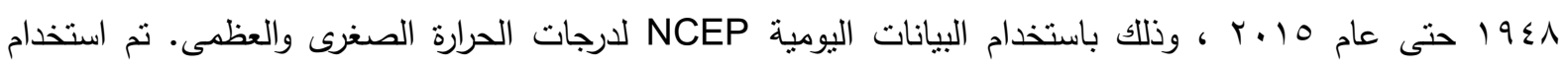

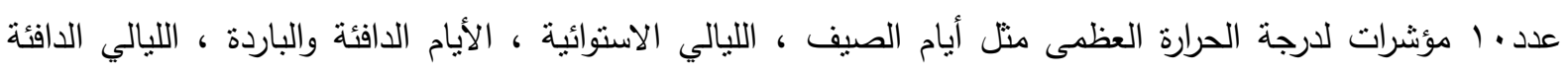

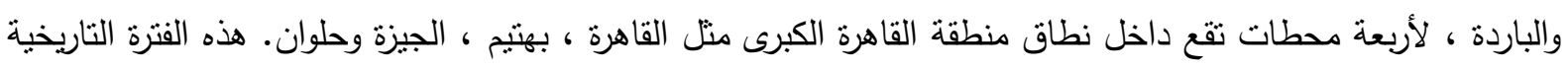

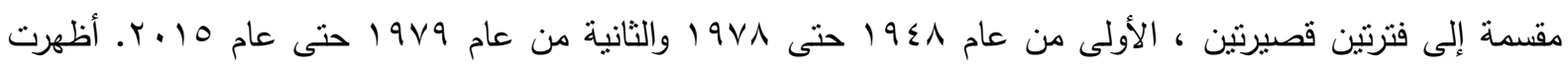

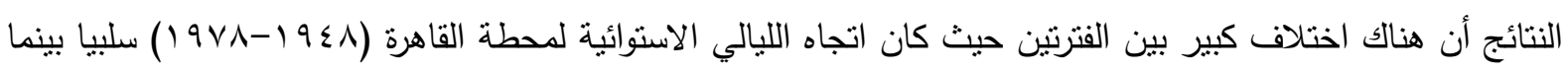

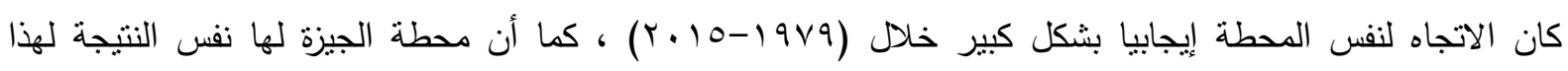

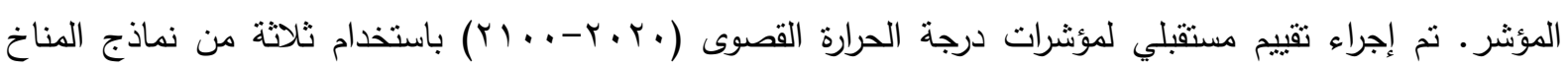
العالمية CMIP5 مع اثثين من السيناريوهات المحتملة أحدها سيناريو متفائل وهو

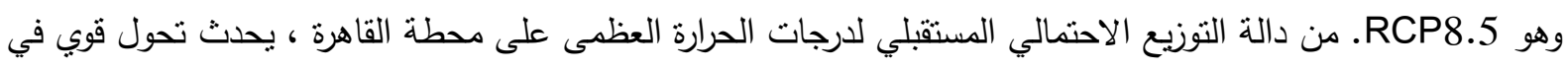
المتوسط لأيام الصيف عند RCP8.5 أكثر من RCP4.5 مما يؤدي إلى مزيد من حالات الطقس الحار والطقس البارد.

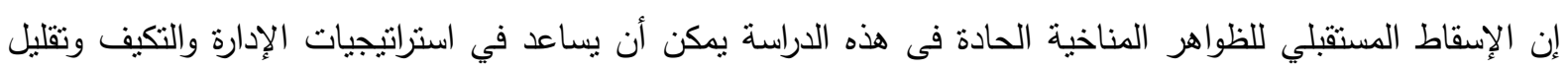
الاثار السلبية المحتملة للتغير المناخى على قطاعات مختلفة كالزراعة والصحة. كلمات مفتاحية: القاهرة الكبرى - مصر - المؤشرات الحادة - نماذج المناخ العالمية- سيناريو متفائل - سيناريو 